\title{
Effect of Combined Wet Alkaline Mechanical Pretreatment on Enzymatic Hydrolysis of Corn Stover and Its Mechanism
}

\author{
Suan Shi ( $\nabla$ suanshi@cau.edu.cn ) \\ China Agricultural University \\ Jie Yang \\ China Agricultural University \\ Chongfeng Gao \\ China Agricultural University \\ Xueqi Yang \\ China Agricultural University \\ Yanfu Su \\ China Agricultural University \\ Lujia Han \\ China Agricultural University
}

Research Article

Keywords: Corn stover, Mechanochemistry, Pretreatment, Glucose yield, Correlation

Posted Date: January 24th, 2022

DOI: https://doi.org/10.21203/rs.3.rs-1272625/v1

License: (c) (1) This work is licensed under a Creative Commons Attribution 4.0 International License. Read Full License 


\begin{abstract}
Background: To further optimize the mechanochemical pretreatment process, a combined wet alkaline mechanical pretreatment of corn stover at room temperature was proposed.
\end{abstract}

Results: The combined alkaline mechanical pretreatment significantly enhanced enzymatic hydrolysis resulting in a glucose yield $\left(\mathrm{Y}_{\mathrm{G}}\right)$ of $491.9 \mathrm{mg} / \mathrm{g}(91.9 \%)$ with $3 \% \mathrm{NaOH}$ and ball milling for $10 \mathrm{~min}$. The liquid fraction after treatment contained by-products such as monosaccharides, oligosaccharides, acetic acid, and lignin but no furfural and 5-hydroxymethylfurfural. Quantitative correlation analysis showed that $\mathrm{Y}_{\mathrm{G}}=41.41+4.09^{\prime}$ ball milling time (min) $+112.7^{\prime} \mathrm{NaOH}$ concentration (\%) $\left(R^{2}=0.87\right), Y_{G}=37.79$ 'cellulose content $-1421.55\left(R^{2}=0.88\right)$, and $Y_{G}=-72.47$ lignin content $+1482.77\left(R^{2}=0.95\right)$.

Conclusion: The impact of the physical and chemical properties of corn stover pretreated with different ball milling times and/or different $\mathrm{NaOH}$ concentrations on the subsequent enzymatic hydrolysis was investigated, which would be beneficial to illustrate the effective mechanism of mechanochemical pretreatment method.

\title{
Background
}

With the extensive development and application of fuel ethanol worldwide, lignocellulosic biomass, such as straw, has become a raw material source for fuel ethanol production owing to its advantages of large output and availability[1-3]. However, lignocellulosic biomass has a complex microstructure and chemical composition. A dense macromolecular network composed of cellulose, hemicellulose, and lignin in the cell wall of lignocellulosic biomass improves its recalcitrance of cellulose to chemical reagents and enzymes, seriously hindering the ethanol conversion efficiency[4]. Therefore, pretreatment of lignocellulosic biomass is generally required to reduce its biological resistance and increase the ethanol conversion efficiency[5].

Alkaline pretreatment using sodium hydroxide $(\mathrm{NaOH})$ solution is a common and efficient chemical pretreatment method for lignocellulose. This process improves the accessibility of cellulose to enzymes by cleaving ester and ether bonds in lignin and hemicellulose through degreasing and saponification, and removing lignin and some hemicellulose in plant cell walls[6-9]. The alkaline pretreatment process doesn't require expensive and complicated equipment, but long reaction times or high reaction temperatures are often needed to achieve desired efficiency in the subsequent enzymatic hydrolysis [10]. For example, Li et al. mixed corn stover with $7 \mathrm{wt} \%$ and $10 \mathrm{wt} \% \mathrm{NaOH}$ solutions at a mass ratio of $1: 10$, followed by grinding for 30 min at 140 and $160^{\circ} \mathrm{C}$, obtaining the maximum glucose yield from enzymatic hydrolysis after pretreatment using $10 \mathrm{wt} \% \mathrm{NaOH}$ at $160{ }^{\circ} \mathrm{C}[11]$.

Ball milling pretreatment is an environmentally friendly physical pretreatment method that can disrupt the dense and complex physical structure of plant cell walls, reduce the size of biomass particles, destroy the crystalline structure of cellulose, and increase the degree of exposure to cellulose through mechanical force, which result in increased enzymatic hydrolysis efficiency[12-14]. Ji et al. reported that the glucose yield from enzymatic hydrolysis of rice straw increased after ball milling for 20 min owing to the average particle size being at the cellular scale $(<30-50 \mu \mathrm{m})$, destruction of the straw cell wall structure, and reduced crystallinity[15]. Although the ball milling process is environmentally friendly, pollution-free, and cannot change the original chemical composition of biomass, its energy consumption is high[14].

Recently, to utilize the advantages of alkaline and mechanical pretreatments while avoiding the problems of single pretreatment, mechanochemical pretreatment has attracted research attention[16-18]. Barakat et al. mixed wheat straw with $\mathrm{NaOH}$ solution and ammonia $(5 \% \mathrm{w} / \mathrm{w})$ in a $5: 1(\mathrm{w} / \mathrm{v})$ ratio at room temperature for $5 \mathrm{~h}$ and then the mixtures were ball-milled after drying in an oven at $105^{\circ} \mathrm{C}$ [19]. Chuetor et al. mixed bagasse with $\mathrm{NaOH}(5 \% \mathrm{w} / \mathrm{w})$ at a ratio of $1: 2$ or $1: 5(\mathrm{w} / \mathrm{v})$ for $3 \mathrm{~h}$, followed by centrifugal grinding treatment after drying (maintaining moisture at $8-10 \%$ ) in $60^{\circ} \mathrm{C}$ oven[20]. The above combined mechanochemical treatments can enhance enzymatic hydrolysis efficiency, but the long treatment time and drying step are not favorable for industrial process.

Therefore, to further reduce treatment times and avoid energy consumption in the drying process, a combined wet alkaline mechanical pretreatment at room temperature was proposed in this study. The relationships of the microstructure and chemical composition of corn stover treated with different ball milling times and/or different concentrations of $\mathrm{NaOH}$ with the corresponding glucose yield from enzymatic hydrolysis were analyzed. The composition change of liquid fraction was explored with a view to providing experimental data to elucidate the effective mechanism of mechanochemical pretreatment method.

\section{Results And Discussion}

\section{Effects of different pretreatments on yield from enzymatic hydrolysis of corn stover}

Figure 1 shows the glucose yields and Figure 2 shows the xylose yields (b) from treated corn stover. The sugar yields of control group were $65.5 \mathrm{mg} / \mathrm{g}$ (SY $=14.5 \%)$ of glucose yield and $11.8 \mathrm{mg} / \mathrm{g}(\mathrm{SY}=4.7 \%)$ of xylose yield. For samples treated only by ball milling (WBMx-NaOHO\%), the yield of glucose and $\mathrm{xylose}$ increased with increasing ball milling time and reached maximum of $137.9 \mathrm{mg} / \mathrm{g}$ (SY =31.2\%) glucose yield and $30.9 \mathrm{mg} / \mathrm{g}(\mathrm{SY}=12.3 \%) \mathrm{xylose}$ yield at 20 min. The relationship between glucose yield $\left(Y_{G}\right)$ and ball milling time $(x)$ can be fitted as the following exponential function, $Y_{G}=164.19-99.34$ '0.94 $\left(R^{2}=\right.$ 0.98) (Fig. 3). For corn stover only treated with $\mathrm{NaOH}$ (WBMO-NaOHy), both the glucose yield and xylose yield significantly increased with increased $\mathrm{NaOH}$ concentration. At a $\mathrm{NaOH}$ concentration of $3 \%$, the glucose yield was $307.1 \mathrm{mg} / \mathrm{g}$ (SY =60.8\%), and the xylose yield was $110.8 \mathrm{mg} / \mathrm{g}(\mathrm{SY}=42.6 \%)$. The quantitative relationship between glucose yield and $\mathrm{NaOH}$ concentration (y) was represented by the following equation: $Y_{G-W B M 0}=74.17 \exp (0.48 \mathrm{y})\left(R^{2}=0.98\right)$ (Fig. 4). By comparison, the effect of $\mathrm{NaOH}$ treatment on the enhancement in enzymatic hydrolysis was higher than that of ball milling.

For the samples treated with combined wet alkaline mechanical, the glucose yield clear increased and the xylose yield showed a trend of increasing first and then decreasing with increasing $\mathrm{NaOH}$ concentration at the same ball milling time. However, when the ball milling time exceeded 10 min, the glucose yield 
showed no clear change. The relationship between $\mathrm{NaOH}$ concentration and glucose yield could be correlated using the following exponential function: $\mathrm{Y}_{\mathrm{G}}$ WBM10-30 $=156.05 \exp (0.39 \mathrm{y})\left(R^{2}=0.90\right)$ (Fig. 4). The highest glucose yield of $491.4 \mathrm{mg} / \mathrm{g}(\mathrm{SY}=91.9 \%)$ could be obtained from WBM10-NaOH3\%, and the highest xylose of $157.9 \mathrm{mg} / \mathrm{g}(\mathrm{SY}=62.1 \%)$ could be obtained from WBM10-NaOH2\%. Therefore, compared with a single mechanical or chemical pretreatment method, combined wet alkaline mechanical pretreatment had a multiplicative effect on the glucose yield efficiency, which greatly enhanced the enzymatic hydrolysis from corn stover. Further binary analysis (Fig. 5) showed that the relationship of ball milling time and $\mathrm{NaOH}$ concentration with the glucose yield could be fitted with the following plane function: $Y_{G}=41.41+4.09 x+112.78 y\left(R^{2}=0.87\right)$.

\section{Mechanistic analysis of the enhancement of enzymatic hydrolysis efficiency by mechanochemical pretreatment based on physical and chemical characterization}

According to scanning electron micrographs of corn stover from different pretreatments (see Fig.6), the particle size of samples was reduced after ball milling for $10 \mathrm{~min}$, but the morphology and size of the particles did not change much with increased milling time.

The particle size distribution curves for corn stover from different pretreatments were shown in Figure 7. Furthermore, Table 1 shows the changes of microstructure parameters and main chemical compositions of corn stover with different pretreatments. Table 2 showed the Pearson correlation analysis results.

Table 1

Microstructural parameters and main chemical composition changes of corn stover from different pretreatments.

\begin{tabular}{|c|c|c|c|c|c|c|c|c|c|}
\hline \multirow[t]{2}{*}{ Sample } & \multirow[t]{2}{*}{$\mathrm{D}_{50}(\mu \mathrm{m})$} & \multirow[t]{2}{*}{ Crystallinity (\%) } & \multicolumn{3}{|l|}{ solid } & \multicolumn{4}{|l|}{ liquid } \\
\hline & & & Cellulose (\%) & Hemicellulose (\%) & Lignin (\%) & $\begin{array}{l}\text { Glucose } \\
\left(\mathrm{mg} / \mathrm{g}^{[1]}\right)\end{array}$ & $\begin{array}{l}\text { Xylose } \\
(\mathrm{mg} / \mathrm{g})\end{array}$ & $\begin{array}{l}\text { Arabinose } \\
(\mathrm{mg} / \mathrm{g})\end{array}$ & $\begin{array}{l}\text { Acetic } \\
\text { acid } \\
\text { (mg/g) }\end{array}$ \\
\hline $\begin{array}{l}\text { WBMO- } \\
\mathrm{NaOH0} \%\end{array}$ & $182.8 \pm 8.2^{j}$ & $43.8 \pm 3.0^{e f}$ & $40.5 \pm 0.3^{a b}$ & $26.8 \pm 0.2^{\mathrm{ab}}$ & $19.4 \pm 0.4^{d}$ & $46.5 \pm 0.1^{d}$ & $15.9 \pm 0.2^{\mathrm{a}}$ & $2.1 \pm 0.0^{\mathrm{a}}$ & $1.1 \pm 0.0^{\mathrm{a}}$ \\
\hline $\begin{array}{l}\text { WBMO- } \\
\text { NaOH1\% }\end{array}$ & $226.6 \pm 10.9^{k}$ & $42.9 \pm 1.1^{\mathrm{e}}$ & $42.4 \pm 0.1^{\mathrm{bcd}}$ & $28.2 \pm 0.3^{\mathrm{bcd}}$ & $17.8 \pm 0.4^{\mathrm{cd}}$ & $49.6 \pm 0.2^{g}$ & $19.6 \pm 0.1 b^{a}$ & $3.4 \pm 0.0^{b}$ & $25.4 \pm 0.2^{\mathrm{e}}$ \\
\hline $\begin{array}{l}\text { WBMO- } \\
\mathrm{NaOH} 2 \%\end{array}$ & $250.2 \pm 13.1^{\prime}$ & $47.1 \pm 0.2^{f}$ & $44.2 \pm 0.3^{\text {edf }}$ & $28.6 \pm 0.2^{\text {cde }}$ & $16.7 \pm 0.6^{c}$ & $51.8 \pm 0.0^{h}$ & $25.1 \pm 0.1^{\mathrm{de}}$ & $5.8 \pm 0.0^{\mathrm{h}}$ & $33.3 \pm 0.0^{\mathrm{j}}$ \\
\hline $\begin{array}{l}\text { WBMO- } \\
\text { NaOH3\% }\end{array}$ & $283.8 \pm 7.6^{\mathrm{m}}$ & $43.6 \pm 1.8^{\mathrm{ef}}$ & $45.5 \pm 1.2^{\mathrm{fgh}}$ & $28.4 \pm 0.6^{\mathrm{cd}}$ & $14.4 \pm 0.6^{a}$ & $54.7 \pm 0.2^{j}$ & $36.2 \pm 0.3^{f}$ & $8.1 \pm 0.1^{i}$ & $34.1 \pm 0.0^{1}$ \\
\hline $\begin{array}{l}\text { WBM10- } \\
\text { NaOH0\% }\end{array}$ & $81.5 \pm 1.2^{\mathrm{fg}}$ & $41.5 \pm 0.7^{\mathrm{de}}$ & $39.5 \pm 1.3^{a}$ & $26.5 \pm 0.6^{a}$ & $18.1 \pm 0.7^{\mathrm{cd}}$ & $46.7 \pm 0.1^{\text {ef }}$ & $21.9 \pm 0.1^{\mathrm{Bb}}$ & $3.4 \pm 0.0^{b}$ & $1.7 \pm 0.0^{b}$ \\
\hline $\begin{array}{l}\text { WBM10- } \\
\text { NaOH1\% }\end{array}$ & $86.5 \pm 0.7^{\mathrm{gh}}$ & $40.5 \pm 0.9^{\text {cde }}$ & $42.7 \pm 0.2^{\mathrm{abcd}}$ & $29.0 \pm 0.2^{\mathrm{de}}$ & $16.5 \pm 0.9^{b c}$ & $41.9 \pm 0.1^{c}$ & $20.5 \pm 0.0^{b}$ & $4.8 \pm 0.0^{f}$ & $29.6 \pm 0.2^{g}$ \\
\hline $\begin{array}{l}\text { WBM10- } \\
\mathrm{NaOH} 2 \%\end{array}$ & $94.0 \pm 0.8^{\mathrm{hi}}$ & $41.2 \pm 0.4^{\mathrm{de}}$ & $46.6 \pm 0.8^{g h i}$ & $28.3 \pm 0.8^{\mathrm{bcd}}$ & $14.8 \pm 0.1^{\mathrm{ab}}$ & $47.0 \pm 0.0^{f}$ & $52.4 \pm 0.1^{g}$ & $16.7 \pm 0.0^{j}$ & $31.4 \pm 0.0^{i}$ \\
\hline $\begin{array}{l}\text { WBM10- } \\
\text { NaOH3\% }\end{array}$ & $96.1 \pm 0.6^{i}$ & $42.7 \pm 1.4^{e}$ & $48.1 \pm 0.2^{\mathrm{ijk}}$ & $26.6 \pm 0.3^{a}$ & $14.3 \pm 0.1^{\mathrm{a}}$ & $60.2 \pm 0.1^{\mathrm{m}}$ & $98.8 \pm 0.1^{i}$ & $24.1 \pm 0.0^{1}$ & $35.7 \pm 0.0^{\mathrm{m}}$ \\
\hline $\begin{array}{l}\text { WBM20- } \\
\mathrm{NaOH0} \%\end{array}$ & $37.3 \pm 0.2^{b}$ & $36.6 \pm 0.6^{a b}$ & $39.9 \pm 1.2^{\mathrm{a}}$ & $27.0 \pm 0.8^{a b c}$ & $17.0 \pm 0.4^{c}$ & $56.5 \pm 0.2^{k}$ & $24.2 \pm 0.2^{d}$ & $3.7 \pm 0.0^{c}$ & $2.2 \pm 0.1^{c}$ \\
\hline $\begin{array}{l}\text { WBM20- } \\
\mathrm{NaOH} 1 \%\end{array}$ & $50.3 \pm 0.2^{c}$ & $38.4 \pm 1.0^{\mathrm{bcd}}$ & $44.7 \pm 0 .{ }^{\text {efg }}$ & $30.1 \pm 0.4^{e}$ & $17.4 \pm 0.4^{c}$ & $46.2 \pm 0.0^{d}$ & $22.6 \pm 0.1^{\mathrm{Ad}}$ & $5.0 \pm 0.0^{g}$ & $28.1 \pm 0.1^{f}$ \\
\hline $\begin{array}{l}\text { WBM20- } \\
\mathrm{NaOH} 2 \%\end{array}$ & $65.3 \pm 0.3^{\mathrm{de}}$ & $37.4 \pm 1.5^{\mathrm{abc}}$ & $47.7 \pm 0.9^{\text {hij }}$ & $28.9 \pm 0.4^{\mathrm{de}}$ & $14.8 \pm 0.5^{\mathrm{ab}}$ & $49.8 \pm 0.1^{g}$ & $56.0 \pm 0.0^{h}$ & $17.7 \pm 0.0^{k}$ & $31.0 \pm 0.1^{\mathrm{h}}$ \\
\hline $\begin{array}{l}\text { WBM20- } \\
\text { NaOH3\% }\end{array}$ & $77.2 \pm 0.3^{f}$ & $35.2 \pm 0.7^{\mathrm{ab}}$ & $50.1 \pm 0.2^{\mathrm{kl}}$ & $27.0 \pm 0.7^{a b c}$ & $14.5 \pm 0.3^{a}$ & $58.5 \pm 0.0^{1}$ & $102.2 \pm 0.3^{j}$ & $24.1 \pm 0.0^{1}$ & $33.7 \pm 0.2^{k}$ \\
\hline $\begin{array}{l}\text { WBM30- } \\
\mathrm{NaOH0 \%}\end{array}$ & $27.1 \pm 0.2^{\mathrm{a}}$ & $33.6 \pm 0.4^{a}$ & $41.6 \pm 0.9^{a b c}$ & $28.5 \pm 0.4^{\mathrm{cd}}$ & $17.7 \pm 1.0^{\mathrm{C}}$ & $40.4 \pm 0.1^{b}$ & $25.6 \pm 0.2^{\mathrm{e}}$ & $3.9 \pm 0.0^{d}$ & $1.3 \pm 0.0^{\mathrm{a}}$ \\
\hline $\begin{array}{l}\text { WBM30- } \\
\text { NaOH1\% }\end{array}$ & $37.7 \pm 0.1^{b}$ & $36.1 \pm 1.1^{\mathrm{ab}}$ & $43.2 \pm 0.6^{\text {cde }}$ & $29.3 \pm 0.4^{\text {de }}$ & $16.5 \pm 0.9^{b c}$ & $37.6 \pm 0.2^{\mathrm{a}}$ & $19.8 \pm 0.0^{\mathrm{b}}$ & $4.5 \pm 0.0^{\mathrm{e}}$ & $23.6 \pm 0.2^{d}$ \\
\hline $\begin{array}{l}\text { WBM30- } \\
\mathrm{NaOH} 2 \%\end{array}$ & $56.8 \pm 0.1^{c d}$ & $34.0 \pm 0.1^{a}$ & $49.6 \pm 0.7^{\mathrm{jkl}}$ & $29.3 \pm 0.5^{\text {de }}$ & $14.4 \pm 0.3^{a}$ & $54.0 \pm 0.0^{i}$ & $56.1 \pm 0.3^{h}$ & $17.7 \pm 0.1^{\mathrm{k}}$ & $34.3 \pm 0.1^{1}$ \\
\hline $\begin{array}{l}\text { WBM30- } \\
\text { NaOH3\% }\end{array}$ & $67.4 \pm 0.4^{\mathrm{e}}$ & $35.4 \pm 0.5^{\mathrm{ab}}$ & $50.7 \pm 0.6^{1}$ & $26.2 \pm 0.2^{a}$ & $14.3 \pm 0.0^{a}$ & $61.7 \pm 0.2^{n}$ & $103.3 \pm 1.3^{k}$ & $25.3 \pm 0.2^{m}$ & $35.6 \pm 0.1^{m}$ \\
\hline
\end{tabular}

Note: (1) $\mathrm{mg} / \mathrm{g}$ corn stover before pretreatment. (2) Different lowercase letters in the same column indicate significant differences $(\mathrm{P}<0.01)$. 
According to the results in Figure 7 and Table 1, the average particle size $\left(\mathrm{D}_{50}\right)$ of corn stover without mechanochemical treatment (WBM0-NaOH0) was $182.8 \pm 8.2 \mathrm{~mm}$, which was at the tissue scale $(100-500 \mathrm{~mm})$ [21]. For corn stover subjected to wet ball milling treatment, the $D_{50}$ was reduced from $81.5 \pm 1.2$ $\mathrm{mm}$ at $10 \mathrm{~min}$ to $27.1 \pm 0.2 \mathrm{~mm}$ at $30 \mathrm{~min}$, which was at cellular scale. The plant tissue structure and hydrogen bonds between crystalline cellulose were destroyed by mechanical forces, resulting in decreased crystallinity[14, 21]. Although cellulose macromolecules in ball-milled samples were hardly depolymerized, the cellulose exposure was increased owing to the increase in specific surface area, which was beneficial to improving the enzymatic hydrolysis efficiency to some extent [22-24]. For $\mathrm{NaOH}$ pretreatment, as shown in Table 1, the crystallinity of corn stover did not change much with increased $\mathrm{NaOH}$ concentration, which was due to the overall $\mathrm{NaOH}$ loading being low $[23,24]$. However, the $\mathrm{D}_{50}$ value increased $(\mathrm{p}<0.01)$ owing to the swelling effect of $\mathrm{NaOH}$ solution on corn stover [20]. The removal of lignin and hemicellulose from the solids by $\mathrm{NaOH}$ resulted in a significant increase in the proportion of cellulose and a significant decrease in the lignin content $(\mathrm{p}<0.01)$, while the hemicellulose content decreased only slightly. Compared with the contents of liquid fraction, it could be seen that the xylose content increased $127.8 \%$ from $15.9 \mathrm{mg} / \mathrm{g}$ (WBMO-NaOH 0\%) to $36.2 \mathrm{mg} / \mathrm{g}$ (WBM0-NaOH $3 \%$ ). The arabinose and acetic acid contents also showed a similar pattern of change, which indicated that the increase in $\mathrm{NaOH}$ concentration made more hemicellulose decompose into monosaccharides or oligosaccharides, resulting in no discernable increase of content in the solid[7]. According to previous research, lignin could cause non-productive binding with cellulase, and limit the accessibility of xylan to enzymes[25-27]. Therefore, the glucose and xylose yield increased with the lignin content decreasing by $\mathrm{NaOH}$ pretreatment, which was consistent with the correlation analysis results in Table 2.

There was no furfural or HFM formation during the combined wet alkaline mechanical pretreatment. With the same ball milling time, the particle size of treated samples increased (Fig. 7), and the cellulose characteristic diffraction peak intensity weakened with increased $\mathrm{NaOH}$ solution concentration (Fig. 8). Furthermore, the data in Table 2 shows that samples subjected to mechanochemical pretreatment had decreased size and crystallinity, with the trend similar to that observed for samples subjected to single ball milling pretreatment. The changes in chemical characteristics caused by single $\mathrm{NaOH}$ treatment, including the increased cellulose content and lignin removal, were further enhanced by mechanochemical pretreatment. For example, the cellulose content of WBMO- $\mathrm{NaOHO} \%$ was $40.5 \%$, which was increased to $45.5 \%$ after treatment with $3 \% \mathrm{NaOH}$ and $50.7 \%$ after treatment with $3 \% \mathrm{NaOH}$ and ball milling for 30 min. Furthermore, the decrease in crystallinity and increase in average particle size caused by the swelling effect of $\mathrm{NaOH}$ contributed to promoting the diffusion of cellulase molecules and the accessibility of cellulose to the enzyme, which resulted in a much greater effect on the glucose yield, as shown in Fig. 4 [23].

Table 2

Pearson correlation analysis

\begin{tabular}{|c|c|c|c|c|c|c|c|c|c|}
\hline & $\begin{array}{l}\mathrm{NaOH} \\
\text { concentration } \\
(\%)\end{array}$ & $\begin{array}{l}\text { WBM } \\
\text { (min) }\end{array}$ & $\mathrm{D}_{50}(\mu \mathrm{m})$ & $\begin{array}{l}\text { Crystallinity } \\
(\%)\end{array}$ & $\begin{array}{l}\text { Cellulose } \\
(\%)\end{array}$ & $\begin{array}{l}\text { Hemicellulose } \\
(\%)\end{array}$ & $\begin{array}{l}\text { Lignin } \\
(\%)\end{array}$ & $\begin{array}{l}\text { Glucose } \\
\text { yield } \\
\text { (mg/g) }\end{array}$ & $\begin{array}{l}\text { Xylose yield } \\
(\mathrm{mg} / \mathrm{g})\end{array}$ \\
\hline $\begin{array}{l}\mathrm{NaOH} \\
\text { concentration } \\
(\%)\end{array}$ & 1 & 0 & 0.260 & 0.43 & $0.893^{* *}$ & -0.406 & $-0.897^{\star *}$ & $0.884^{* *}$ & $0.787^{\star *}$ \\
\hline WBM (min) & & 1 & $-0.837^{\star \star}$ & $-0.945^{\star *}$ & 0.338 & -0.403 & -0.282 & 0.321 & 0.206 \\
\hline $\mathrm{D}_{50}(\mu \mathrm{m})$ & & & 1 & $0.807^{\star \star}$ & 0.090 & 0.099 & 0.057 & -0.169 & -0.060 \\
\hline Crystallinity (\%) & & & & 1 & -0.304 & 0.089 & 0.258 & -0.270 & -0.124 \\
\hline Cellulose (\%) & & & & & 1 & -0.404 & $-0.884^{* *}$ & $0.944^{* *}$ & $0.821^{* *}$ \\
\hline $\begin{array}{l}\text { Hemicellulose } \\
(\%)\end{array}$ & & & & & & 1 & 0.333 & -0.370 & -0.242 \\
\hline Lignin (\%) & & & & & & & 1 & $-0.939^{\star *}$ & $-0.882^{* *}$ \\
\hline $\begin{array}{l}\text { Glucose yield } \\
(\mathrm{mg} / \mathrm{g})\end{array}$ & & & & & & & & 1 & $0.886^{\star *}$ \\
\hline $\begin{array}{l}\text { Xylose yield } \\
(\mathrm{mg} / \mathrm{g})\end{array}$ & & & & & & & & & 1 \\
\hline
\end{tabular}

As shown in Table 2, the ball milling time had a negative effect on the $\mathrm{D}_{50}$ value and crystallinity $(\mathrm{p}<0.01)$. The $\mathrm{NaOH}$ concentration had a positive effect on the cellulose content, glucose yield and xylose yield, while it had a negative effect on the lignin content $(P<0.01)$, which was consistent with the above analysis results. It is worth noting that there was no discernable correlation between xylose yield and hemicellulose content. It is possible that the removal of lignin increased the xylose yield with slight changes of hemicellulose content in the solid, leading to irrelevant relationship between xylose yield and hemicellulose content.

The cellulose content had a positive effect on the glucose yield $(P<0.01)$, while there was no relationship between glucose yield with $D_{50}$ and crystallinity. For example, the cellulose content reached maximum after $10 \mathrm{~min}$ ball mingling in combined alkaline mechanical pretreatment, and further changes in the chemical composition with an extended ball milling time were limited. It was similar to the change trend in glucose yield, as shown in Fig. 1, which may explain the ball milling time and glucose yield showed no clear linear correlation in Table 2. The scatter plot of glucose yield and cellulose content was shown in Fig. 9, in which the relationship was described as the following linear regression equation: $Y_{G}=37.79^{\prime}$ cellulose content $-1421.55\left(R^{2}=0.88\right)$. Li et al. found 
that the glucose yield of different samples treated with ball milling, alkaline hydrogen peroxide and ammonia fiber expansion could be fitted with a univariate linear correlation with their cellulose content[24]. It is consistent with author's results. Also, the cellulose content of the substrate increases regardless of different pretreatments, the glucose yield will increase accordingly within a certain range[24, 28]. The lignin content had a negative effect on the glucose yield $(P<0.01)$. The scatter plot of glucose yield and lignin content was shown in Fig. 10, in which the relationship was described as the following linear regression equations: $Y_{G}=-72.47$ lignin content $+1482.77\left(R^{2}=0.95\right)$. Loustau-Cazalet et al. mentioned that the main reason for the enhancement of enzymatic hydrolysis was the removal of lignin and lignin-carbohydrate complexes rather than the change of cellulose crystallinity in a study of $\mathrm{NaOH}-\mathrm{VBM}$ pretreatment[29].Previously, Ishiguro et al. found a linear negative correlation between glucose yield and lignin content in obtained eucalyptus treated with hydrothermal-mechanical chemical[30]. Yang and Wyman et al. demonstrated that lignin removal facilitated the degradation of corn stover by cellulase[31]. However, Li et al. discovered an unclear correlation between glucose yield and lignin content when studying corn stover by different pretreatment, and Kumar et al. revealed that the reason why lignin hinders glucose yield may depend on its chemical properties rather than content [24, 32].Combined with the previous data, it can be seen that the lignin content of WBMO- $\mathrm{NaOH} 3 \%$ and WBM10- $\mathrm{NaOH} 3 \%$ is basically the same ( $14.4 \%$ and $14.3 \%$, respectively), but the glucose yield of the latter is higher ( $307.1 \mathrm{mg} / \mathrm{g}$ and $491.4 \mathrm{mg} / \mathrm{g}$, respectively). It may be caused by changes in physical properties such as loosening of structure, reduction in particle size and crystallinity, and chemical properties such as increased cellulose content of the latter through wet ball milling treatment. The fitted equation between glucose and lignin content has some limitations, which may be caused by the wet ball milling treatment. It reflects the enhanced effect of the wet ball milling on the $\mathrm{NaOH}$ treatment in the combined mechanochemical pretreatment, while there are limits to this enhancement, as shown by the fact that extending the ball milling time had little effect.

\section{Conclusions}

A combined wet alkaline mechanical pretreatment of corn stover at room temperature was proposed in this study, which significantly enhanced the enzymatic subsequent hydrolysis. The highest glucose yield of $491.4 \mathrm{mg} / \mathrm{g}$ (SY=91.9\%) was obtained after treatment with $3 \% \mathrm{NaOH}$ and ball milling for $10 \mathrm{~min}$, and the highest xylose yield of $157.91 \mathrm{mg} / \mathrm{g}(\mathrm{SY}=62.1 \%)$ was obtained from corn stover treated with $2 \% \mathrm{NaOH}$ and ball milling for 10 min. The quantitative relationships between glucose yield with $\mathrm{NaOH}$ concentration, ball milling time, cellulose content and lignin content were established. The component of liquid fraction after pretreatment was determined and less harmful inhibitors were generated in this pretreatment process.

\section{Materials And Methods Corn stover and reagents}

Corn stover collected from the Shangzhuang Experimental Station in Beijing, China, was dried naturally, chopped into small pieces (3-5 cm), and coarsely milled through a 1-mm sieve using RT-34 milling machine (Hongquan Pharmaceutical Machinery Ltd., China), with the resulting milled corn stover denoted as CM. Its main components were $36.3 \%$ of cellulose, $22.6 \%$ of hemicellulose and $16.9 \%$ of lignin.

Sodium hydroxide (purity, $\geq 96.0 \%$ ) was purchased from Beijing Chemical Plant and used without further purification.

\section{Mechanochemical treatments of corn stover}

CM samples and $\mathrm{NaOH}$ solutions of different concentrations $(0,1,2$, and 3 wt\%) were thoroughly mixed in a 1:6(w/w) ratio (optimized from our preexperiment) and were allowed to stand for a certain period ( $\left.\mathrm{t}_{1}\right)$. An ultrafine vibration ball mill (CJM-SY-B; Qinhuangdao Taiji Ring Nano Ltd., Hebei, China) was then used to crush the above mixture for different amounts of time $t_{2}(0,10,20$, and $30 \mathrm{~min})$ under the optimized conditions obtained from our preliminary tests, in which $\mathrm{ZrO}_{2}$ balls and $\mathrm{CM}$ were mixed in a volume ratio of $2: 1$, with the $\mathrm{ZrO}_{2}$ balls occupying $35 \%$ of the ball mill tank volume. A circulating cooling water was passed around the tank to maintain the temperature at around $25^{\circ} \mathrm{C}$ during the milling process. All samples were in contact with $\mathrm{NaOH}$ solutions of different concentrations for $1 \mathrm{~h}\left(\mathrm{t}_{1}+\mathrm{t}_{2}=1 \mathrm{~h}\right)$. The samples obtained were denoted as $\mathrm{WBMx}-\mathrm{NaOHy}$, where $\mathrm{x}$ was the milling time and $\mathrm{y}$ was the $\mathrm{NaOH}$ concentration. The control treatment was as follows: CM samples were mixed thoroughly with deionized water for $1 \mathrm{~h}$, without ball milling.

The $\mathrm{pH}$ of treated samples was adjusted to neutral $\mathrm{pH}$ by deionized water and dilute hydrochloric acid. The liquid was collected and volume was recorded. $\mathrm{A}$ portion of the solid from treated corn stover was stored at $4{ }^{\circ} \mathrm{C}$ for subsequent enzymatic hydrolysis, and the remaining solid was dried in a vacuum freeze dryer to determine the lignocellulosic composition and crystallinity. The solid yield was calculated using equation (1)[33]:

$$
\text { Solidyield }(\%)=\frac{m_{1}}{m_{2}} 100 \%
$$

1 where $m_{1}$ and $m_{2}$ are the masses $(\mathrm{g})$ of dry matter after and before treatment, respectively.

\section{Particle size distribution measurement}

The particle size distribution of treated samples (diluted to $1 \mathrm{wt} \%$ of the original concentration for measurement) was obtained using a MASTERSIZER 3000 laser particle size analyzer (Malvern, UK)[34]. Particle sizes $D_{10}, D_{50}$, and $D_{90}$, representing $10 \%, 50 \%$, and $90 \%$ of the accumulated volume fraction, respectively, were determined using the obtained particle size distribution curves. Each sample was measured five times. 


\section{Cellulose crystallinity (Crl) analysis}

The cellulose crystallinity ( $\mathrm{Cr}$ ) of the obtained dried samples was measured using a XD3 series X-ray diffractometer (Puxi, Beijing) with Cu Ka radiation at 36 $\mathrm{kV}$ and $20 \mathrm{~mA}$. The diffraction intensity was obtained in the $2 \mathrm{q}$ range of $5-40^{\circ}$ with a step size of $0.2^{\circ}$ at a scanning speed of $2^{\circ} / \mathrm{min}$. Each sample was measured in duplicate. The $\mathrm{Cr}$ was calculated according to equation (2)[35]:

$$
\operatorname{CrI}(\%)=\frac{\mathrm{I}_{\max }-I_{a m}}{I_{a m}} 100 \%
$$

2

where $I_{\max }$ is the maximum intensity of the diffraction peak at approximately $2 \mathrm{q}=22^{\circ}$, and $I_{a m}$ is the intensity of the amorphous background at approximately $2 q=18^{\circ}$.

\section{Scanning electron microscopy (SEM) analysis}

The surface morphologies of treated corn stover were observed using a Hitachi SU3500 electron microscope (Hitachi, Japan). Samples with a concentration of $0.1 \mathrm{wt} \%$ were dropped onto carbon tape, dried in an oven at $60^{\circ} \mathrm{C}$ overnight, and sprayed with gold before subjecting to SEM observation.

\section{Analysis of main chemical components}

The cellulose, hemicellulose, and lignin contents in the solid were measured using the method of NREL-TP-510-42618[36]. Each sample was measured in duplicates.

The total sugar content (monosaccharide and oligosaccharide) of glucose, xylose and arabinose, and byproduct contents such as furfural, 5hydroxymethylfurfural (HFM), acetic acid in liquids were measured according to NREL-TP-510-42623[37]. The acid soluble lignin content was measured according to method NREL-TP-510-42618. Each sample was measured in duplicates.

\section{Enzymatic hydrolysis of corn stover}

The enzymatic hydrolysis of pretreated corn stover was performed using cellulase enzyme of CellicCtec2 (Novozymes, Denmark). Pretreated samples ( $0.5 \mathrm{~g}$ dry basis) and citrate buffer $(\mathrm{pH} 4.8)$ were mixed in a 1:20 (w/v) ratio and were kept at $200 \mathrm{rpm}$ and $50^{\circ} \mathrm{C}$ for $72 \mathrm{~h}$ in a shaking incubator. Tetracycline hydrochloride $(0.08 \mathrm{~g} / \mathrm{L})$ was added and the enzyme loading was $20 \mathrm{FPU} / \mathrm{g}$ solid, according to the method of NREL/TP-510-42623 [38]. Each sample was measured in duplicates. The monomeric sugar concentration was measured after enzymatic hydrolysis using a HPLC (Hitachi, Japan). The glucose or xylose yield $(Y)$ was calculated using the following equation (3):

$$
Y(m g / g)=\frac{c \times V}{m}
$$

3 where $c$ is the monomeric sugar concentration $(\mathrm{mg} / \mathrm{mL})$ in the enzymatic hydrolysate, $V$ is the volume of enzymatic hydrolysate ( $\mathrm{mL}$ ), and $m$ is the amount of pretreated corn stover added into the enzymatic hydrolysis mixture $(\mathrm{g})$.

The enzymatic digestibility of sugars (SY) was calculated using the following equation (4):

$$
S Y(\%)=\frac{m_{e}}{m_{\max }}
$$

4 Where $m_{e}$ is the monomeric sugars weight $(\mathrm{mg})$ of added solid after enzymatic hydrolysis, and $m_{\max }$ is the maximum weight (mg) of monomeric sugars in the solid.

\section{Statistical analysis}

The results of repeated experiments were expressed as means \pm standard deviation. One-way analysis of variance was performed using Duncan's test at the $99 \%$ level $(p<0.01)$ using SPSS 20.0 software. Data fitting was performed using Origin 2018 software.

\section{Declarations}

\section{Authors' contributions}

Jie Yang designed and performed experiments, analyzed samples, and wrote the manuscript; Chongfeng Gao joined in the design of the experiments; Xueqi Yang and Yanfu Su took part in the performance of experiments; Prof. Suan Shi and Prof. Lujia Han joined in the discussion of experimental plans and edited 
the manuscript. All authors read and approved the final manuscript.

\section{Funding}

This study was supported by the Agriculture Research System of China (CARS-36), the Changjiang Scholars and Innovative Research Team in University of Education Ministry of China (IRT_17R105), the Innovative Research Team of the Agriculture and Rural Affairs Ministry of China (45), and the National Natural Science Foundation of China (No. 32001422).

\section{Availability of data and materials}

All data generated or analyzed during this study are included in this published article.

\section{Ethics approval and consent to participate}

Not applicable.

\section{Consent for publication}

Not applicable.

\section{Competing interests}

The authors declare that they have no competing interests.

\section{Acknowledgments}

The authors would thank the instrument shared platform of College of Engineering of China Agricultural University, for the assistance in the SEM analysis.

\section{References}

1. Chen H, Liu J, Chang X, Chen D, Xue Y, Liu P, Lin H, Han S. A review on the pretreatment of lignocellulose for high-value chemicals. Fuel Process Technol.2017; 160:196-206.

2. Hahn-Hägerdal B, Galbe M, Gorwa-Grauslund MF, Lidén G, Zacchi G. Bio-ethanol - the fuel of tomorrow from the residues of today. Trends Biotechnol.2006; 24(12):549-556.

3. Da Silva ASA, Inoue H, Endo T, Yano S, Bon EPS. Milling pretreatment of sugarcane bagasse and straw for enzymatic hydrolysis and ethanol fermentation. Bioresource Technol.2010; 101(19):7402-7409.

4. Mosier N, Wyman C, Dale B, Elander R, Lee YY, Holtzapple M, Ladisch M. Features of promising technologies for pretreatment of lignocellulosic biomass. Bioresour Technol.2005; 96(6):673-86.

5. Talebnia F, Karakashev D, Angelidaki I. Production of bioethanol from wheat straw: An overview on pretreatment, hydrolysis and fermentation. Bioresource Technol.2010; 101(13):4744-4753.

6. Liu C, Xiao Y, Xia X, Zhao X, Peng L, Srinophakun P, Bai F. Cellulosic ethanol production: Progress, challenges and strategies for solutions. Biotechnol Adv.2019; 37(3):491-504.

7. Lorenci Woiciechowski A, Dalmas Neto CJ, Porto De Souza Vandenberghe L, de Carvalho Neto DP, Novak Sydney AC, Letti LAJ, Karp SG, Zevallos Torres LA, Soccol CR. Lignocellulosic biomass: Acid and alkaline pretreatments and their effects on biomass recalcitrance - Conventional processing and recent advances. Bioresource Technol.2020; 304.

8. Sun S, Sun S, Cao X, Sun R. The role of pretreatment in improving the enzymatic hydrolysis of lignocellulosic materials. Bioresource Technol.2016; 199:49-58.

9. Zhang H, Chen L, Lu M, Li J, Han L. A novel film-pore-surface diffusion model to explain the enhanced enzyme adsorption of corn stover pretreated by ultrafine grinding. Biotechnol Biofuels.2016; 9(1):181.

10. Volynets B, Ein-Mozaffari F, Dahman Y. Biomass processing into ethanol: Pretreatment, enzymatic hydrolysis, fermentation, rheology, and mixing. Green Process Synth.2017; 6(1):1-22.

11. Li Q, Gao Y, Wang H, Li B, Liu C, Yu G, Mu X. Comparison of different alkali-based pretreatments of corn stover for improving enzymatic saccharification. Bioresource Technol.2012; 125:193-199.

12. Lin Z, Huang H, Zhang H, Zhang L, Yan L, Chen J. Ball milling pretreatment of corn stover for enhancing the efficiency of enzymatic hydrolysis. Appl Biochem Biotech.2010; 162(7):1872-1880.

13. Gao C, Xiao W, Ji G, Zhang Y, Cao Y, Han L. Regularity and mechanism of wheat straw properties change in ball milling process at cellular scale. Bioresource Technol.2017; 241:214-219. 
14. Barakat A, de Vries H, Rouau X. Dry fractionation process as an important step in current and future lignocellulose biorefineries: A review. Bioresource Technol.2013; 134:362-373.

15. Ji G, Han L, Gao C, Xiao W, Zhang Y, Cao Y. Quantitative approaches for illustrating correlations among the mechanical fragmentation scales, crystallinity and enzymatic hydrolysis glucose yield of rice straw. Bioresource Technol.2017; 241:262-268.

16. Perona A, Hoyos P, Farrán Á, Hernáiz MJ. Current challenges and future perspectives in sustainable mechanochemical transformations of carbohydrates. Green chemistry: an international journal and green chemistry resource : GC.2020; 22(17):5559-5583.

17. Shen F, Xiong X, Fu J, Yang J, Qiu M, Qi X, Tsang DCW. Recent advances in mechanochemical production of chemicals and carbon materials from sustainable biomass resources. Renewable and Sustainable Energy Reviews.2020; 130:109944.

18. Baig KS, Wu J, Turcotte G. Future prospects of delignification pretreatments for the lignocellulosic materials to produce second generation bioethanol. Int J Energ Res.2019; 43(4):1411-1427.

19. Barakat A, Chuetor S, Monlau F, Solhy A, Rouau X. Eco-friendly dry chemo-mechanical pretreatments of lignocellulosic biomass: Impact on energy and yield of the enzymatic hydrolysis. Appl Energ.2014; 113:97-105.

20. Chuetor S, Champreda V, Laosiripojana N. Evaluation of combined semi-humid chemo-mechanical pretreatment of lignocellulosic biomass in energy efficiency and waste generation. Bioresource Technol.2019; 292:121966.

21. Ji G, Gao C, Xiao W, Han L. Mechanical fragmentation of corncob at different plant scales: Impact and mechanism on microstructure features and enzymatic hydrolysis. Bioresource Technol.2016; 205:159-165.

22. Liu H, Chen X, Ji G, Yu H, Gao C, Han L, Xiao W. Mechanochemical deconstruction of lignocellulosic cell wall polymers with ball-milling. Bioresource Technol.2019; 286:121364.

23. Zhang H, Chen L, Li J, Lu M, Han L. Quantitative characterization of enzyme adsorption and hydrolytic performance for ultrafine grinding pretreated corn stover. Bioresource Technol.2017; 234:23-32.

24. Li J, Zhang H, Lu M, Han L. Comparison and intrinsic correlation analysis based on composition, microstructure and enzymatic hydrolysis of corn stover after different types of pretreatments. Bioresource Technol.2019; 293:122016.

25. Kumar R, Wyman CE. Cellulase adsorption and relationship to features of corn stover solids produced by leading pretreatments. Biotechnol Bioeng.2009; 103(2):252-67.

26. Kumar R, Wyman CE. An improved method to directly estimate cellulase adsorption on biomass solids. Enzyme Microb Tech.2008; 42(5):426-433.

27. Pihlajaniemi V, Sipponen MH, Kallioinen A, Nyyssölä A, Laakso S. Rate-constraining changes in surface properties, porosity and hydrolysis kinetics of lignocellulose in the course of enzymatic saccharification. Biotechnol Biofuels.2016; 9(1).

28. Raud M, Kikas T, Sippula O, Shurpali NJ. Potentials and challenges in lignocellulosic biofuel production technology. Renewable and Sustainable Energy Reviews.2019; 111:44-56.

29. Loustau-Cazalet C, Sambusiti C, Buche P, Solhy A, Bilal E, Larzek M, Barakat A. Innovative deconstruction of biomass induced by dry Chemo-Mechanical activation: Impact on enzymatic hydrolysis and energy efficiency. Acs Sustain Chem Eng.2016; 4(5):2689-2697.

30. Ishiguro M, Endo T. Addition of alkali to the hydrothermal-mechanochemical treatment of Eucalyptus enhances its enzymatic saccharification. Bioresour Technol.2014; 153:322-6.

31. Yang B, Wyman CE. Effect of xylan and lignin removal by batch and flowthrough pretreatment on the enzymatic digestibility of corn stover cellulose. Biotechnol Bioeng.2004; 86(1):88-95.

32. Kumar R, Wyman CE. Access of cellulase to cellulose and lignin for poplar solids produced by leading pretreatment technologies. Biotechnol Progr.2009; 25(3):807-819.

33. Qu T, Zhang X, Gu X, Han L, Ji G, Chen X, Xiao W. Ball milling for biomass fractionation and pretreatment with aqueous hydroxide solutions. Acs Sustain Chem Eng.2017; 5(9):7733-7742.

34. Gao C, Yang J, Han L. Systematic comparison for effects of different scale mechanical-NaOH coupling treatments on lignocellulosic components, micromorphology and cellulose crystal structure of wheat straw. Bioresource Technol.2021;326:124786.

35. Lee JW, Kim JY, Jang HM, Lee MW, Park JM. Sequential dilute acid and alkali pretreatment of corn stover: Sugar recovery efficiency and structural characterization. Bioresource Technol.2015; 182:296-301.

36. Sluiter A, Hames B, Ruiz R, Scaralata C, Sluiter J, Templeton D, Crocker D. Determination of structural carbohydrates and lignin in biomass. Golden: National Renewable Energy Laboratory.2008.

37. Sluiter A, Hames B, Ruiz R, Scarlata C, Sluiter J, Templeton D. Determination of sugars, byproducts, and degradation products in liquid fraction process samples. Golden: National Renewable Energy Laborary.2008.

38. Selig M, Weiss N, Ji Y. Enzymatic saccharification of lignocellulosic biomass. Golden: National renewable Energy Laboratory.2008.

\section{Figures}

\section{Figure 1}

Glucose yield of corn stover treated with different pretreatments (different lowercase letters indicate significant differences, $\mathrm{P}<0.01$ ). 


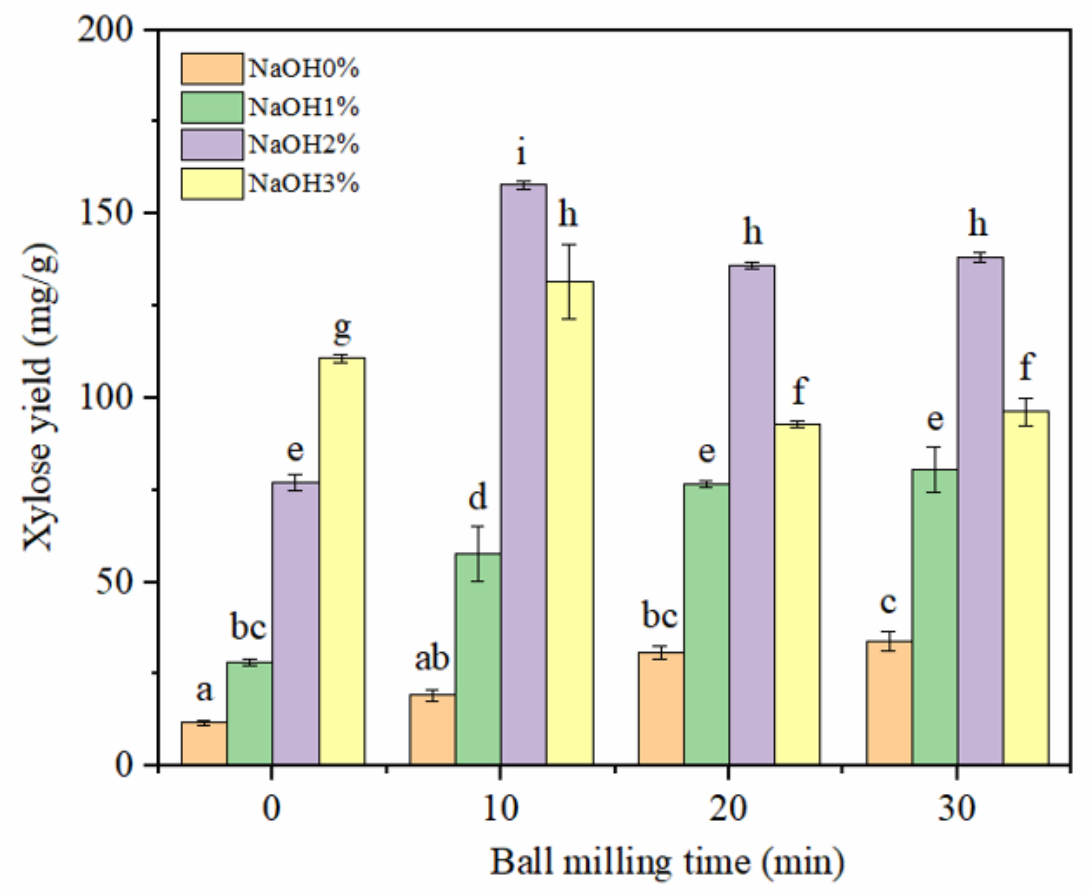

Figure 2

Xylose yield of corn stover treated with different pretreatments (different lowercase letters indicate significant differences, $P<0.01$ ).

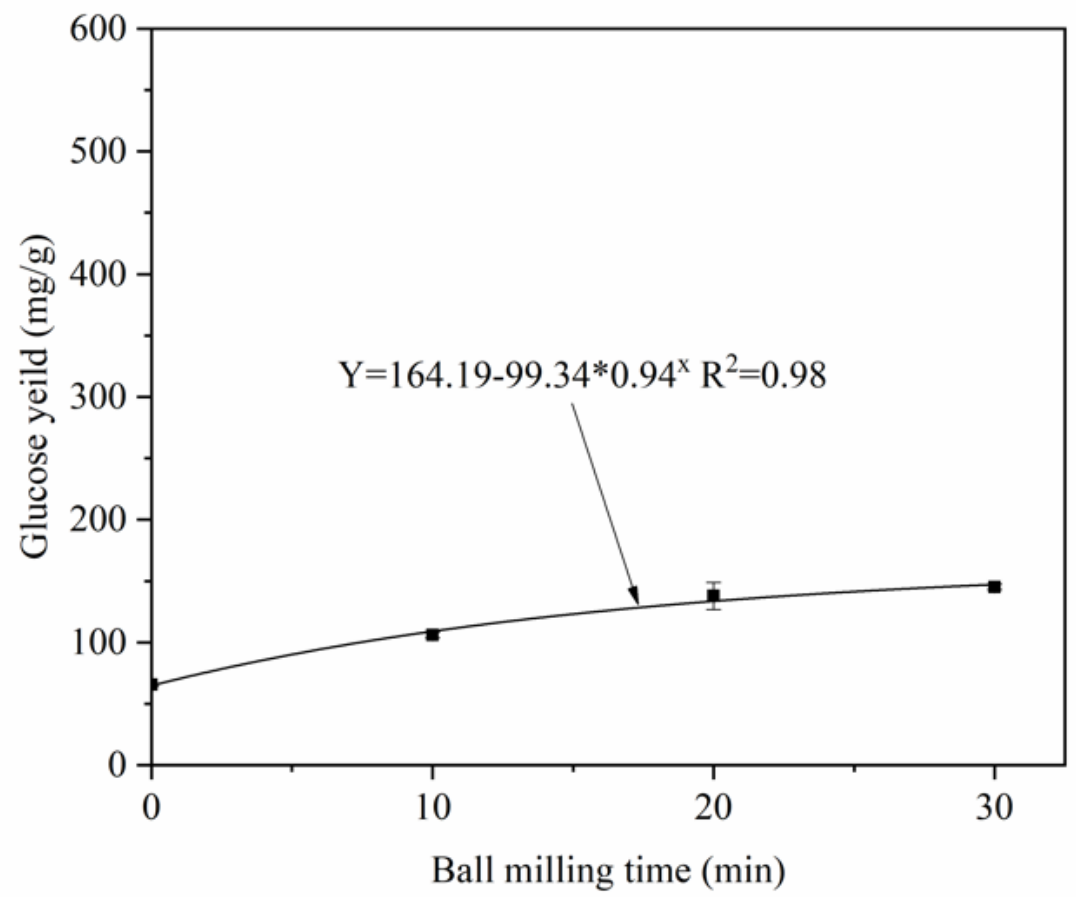

Figure 3

Glucose yield as a function of ball milling time.

Figure 4

Glucose yield as a function of $\mathrm{NaOH}$ concentration. 
Figure 5

Glucose yield as a function of ball milling time and $\mathrm{NaOH}$ concentration.

Figure 6

SEM images of corn stover samples from different pretreatments.

Figure 7

Particle size distribution curve of corn stover from different pretreatments.

Figure 8

X-ray diffraction pattern of corn stover from different pretreatments.

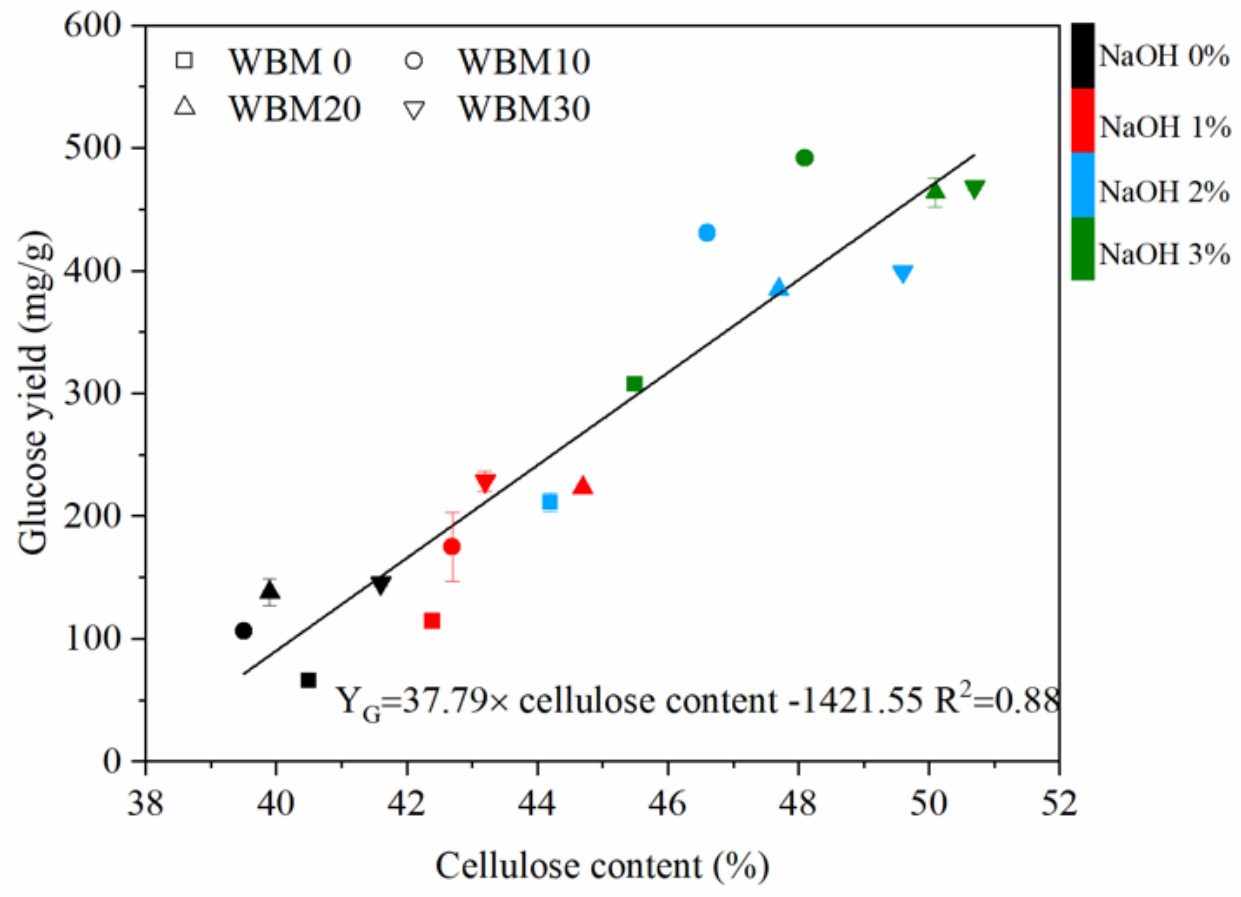

Figure 9

Relationship of glucose yield from corn stover with cellulose content. 


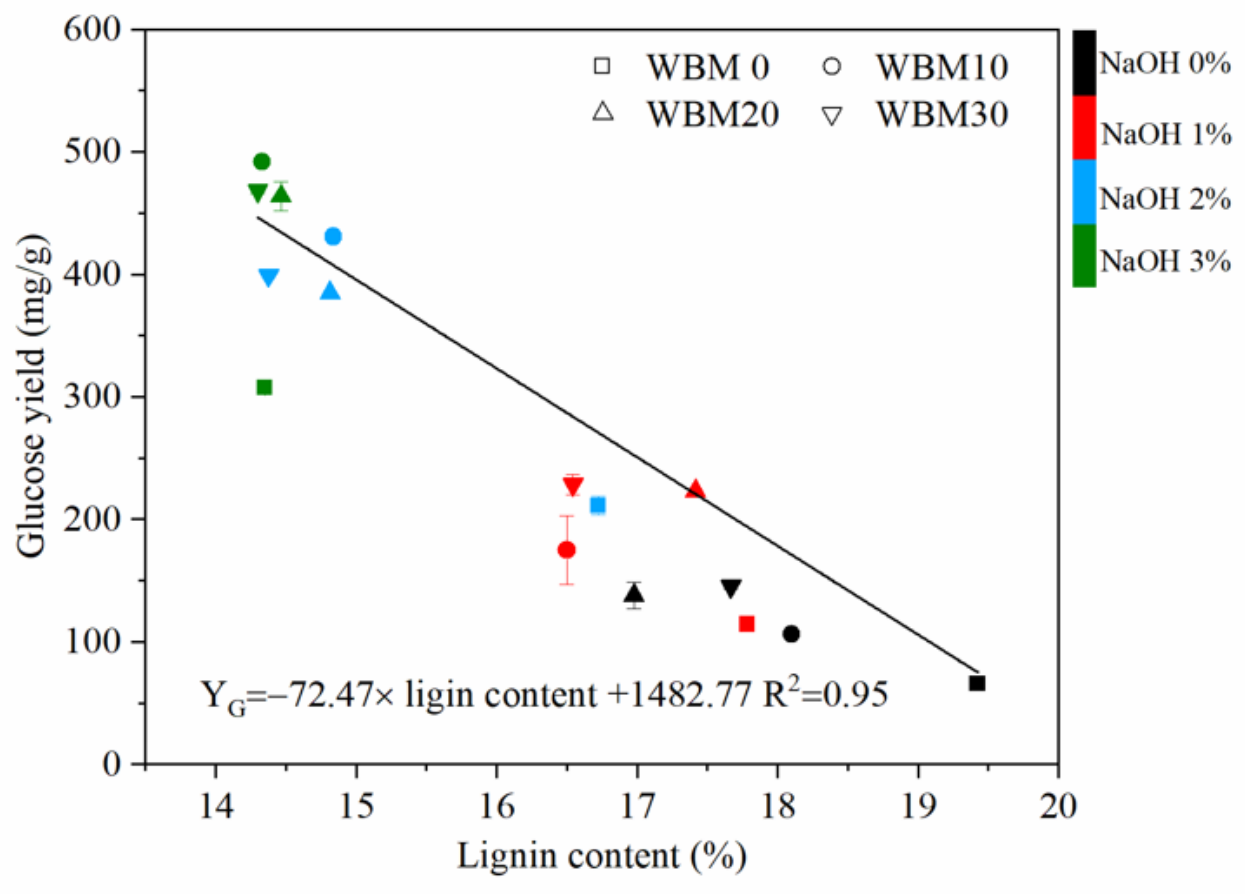

Figure 10

Relationship of glucose yield from corn stover with lignin content. 